Vol. XVII No. 2

\title{
My Favourite Willow
}

\author{
by Hugh McLaughlin, Lewvan, Sask.
}

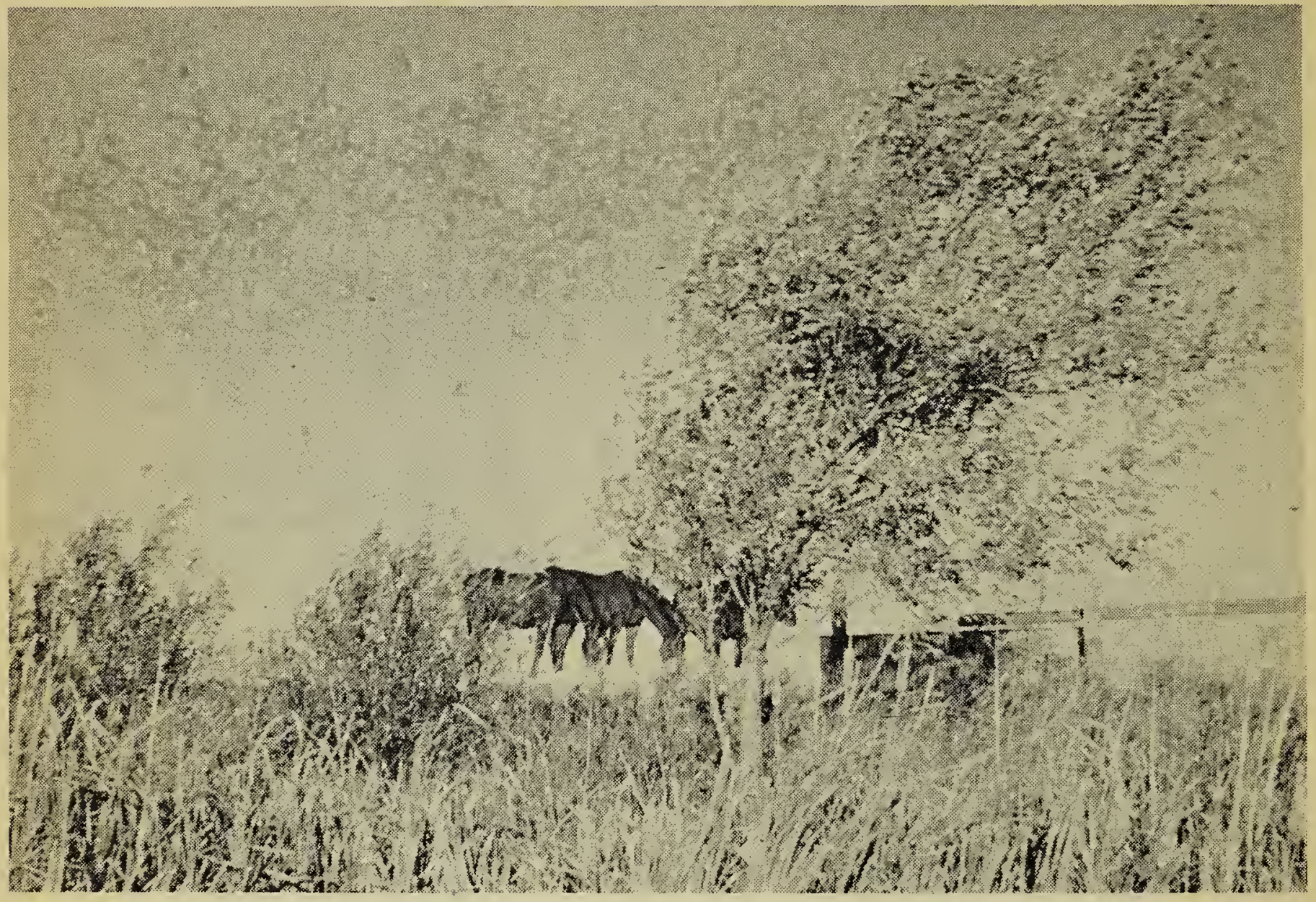

From a Kodachrome by $H$. McLaughlin

THE PEACH-LEAVED WILLOW, Salix amygdaloides

In the summer of 1955, I spent considerable time identifying the various willows that had sprung up along the roadsides as a result of the wet conditions favouring their germination. In making these identifications, I was pleased to have an offer of help from the well-known willow specialist, Carleton R. Ball, who was then 82 years of age, and who had read my article in the Blue Jay in which I told of how I was trying to learn these willows. I should like to pay tribute to him now in writing about my favourite willow tree.

As I predicted then, most of the willows and aspens that sprang pu along the roadsides have since fallen prey to mowers and weed spray. The marsh that was the home of avocets, yellow-headed blackbirds, phalaropes, coots and ducks, that was then so formidable that you could only get into the middle of it on horseback, has now been returned to cultivation. The last vestige of cattail was plowed under this past summer. I did try to save some of the willows by moving them to the creek where they took root with varying degrees of success. From this I conclude that the banks of a prairie creek down which water rushes in the spring do not provide as favourable an environment for the germination of willow seeds as the banks of a roadside ditch where the water is still.

My favourite willow, the peachleaved willow, Salix amygdaloides Anderss., did not mind the racing water of spring or being submerged again by rains in July. It sent out supports a few inches above the base to brace it better in the oozy mud. The pussy and diamond willows simply drowned out; as they did around many sloughs throughout the province. Another willow that survived the ordeal by water was the basket willow, with its round mounds of growth and its leaves which seem to be perpetual hosts to 
a gall; but it is a mere shrub, and not to be compared with the peachleaf.

The next trial was by hail. In June, 1955, came one of the worst hail storms I have ever witnessed. All forms of wildlife suffered. In the sickening mess of reeds and cattails pounded flat, the odd bird limped about. A juvenile short-eared owl glared up at us, grounded by two broken wings. Crops, of course, were flattened to the ground, and even the tough sides of granaries and fence posts showed the marks of hail. Under these conditions trees suffered disastrously. Manitoba maples four years old were simply beaten to pieces, and had to be cut down to the ground the following spring. Young spruce had their branches torn off on one side, although they have since recovered fairly well. A tame pussy willow was badly barked and still presents an unsightly appearance with many dead twigs. But the peach-leaf survived best of all. Its slender branchlets, which hang with almost a droop when in full leaf, were flexible enough to escape with little more than a bruising.

Several of the peach-leaved willows fell prey to beavers, and have come back with a shrubby growth. The one that withstood the hail, however, retains its graceful lines, although the rabbits did prune it one winter when the snow banks were high enough to let them get at its top branches.

In the summer of 1958 when the water in the creek made a swift retreat, when a fairly well established maple and poplar simply dried up and dropped their leaves, it thrived; and like the tree in the poem, it carried a nest in its hair-not a nest of rcibins in this case, but of kingbirds. Long into October, after ash, maple and even elms are bare as skeletons, its leaves welcome the first snows. This is a trait common to some tame willows too, of course, but I believe this native peach-leaf worthy to take its place amid the society of cultivated trees. For myself, I will always value it for the stoic qualities it has shown.

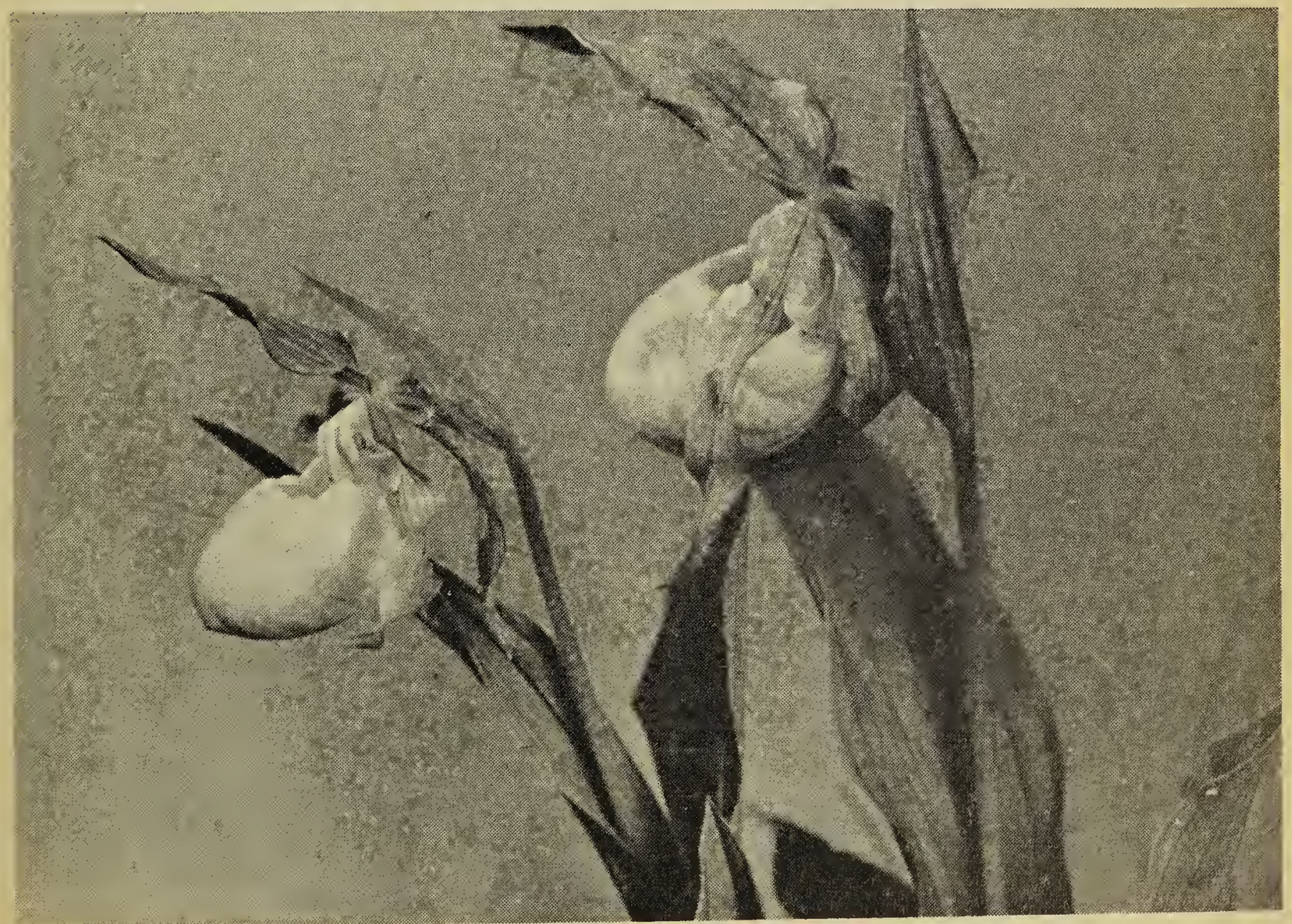

Photo by $W$ Yanchinski

THE YELLOW LADY'S SLIPPER

Cypripedium calceolus L. var. pubescens (Willd.) Correll 